\title{
THE EFFECTS OF DIGITAL MEDIA BUYING ON ADVERTISERS
}

\author{
Lejla Šehic ${ }^{*}$ \\ Almir Peštek ${ }^{* *}$
}

Received: 25. 3. 2020

Professional paper
UDC 004.738.5:659.1 (497.6)
$659.1: 005.1$

Accepted: 15. 5. 2020

DOI https://doi.org/10.30924/mjcmi.25.1.15

\begin{abstract}
Although the Internet has become the essence of communication, from an advertiser's perspective digital advertising remains underexplored. This paper examines the effects of digital media buying efforts on advertisers in Bosnia and Herzegovina, while looking into the methodology of digital media usage behind the actual effects. A combination of secondary research analysis and qualitative research techniques was used. The empirical part is based on in-depth interviews with advertisers and representatives from the digital advertising industry.Perceptions and knowledge of digital advertising are the key drivers for a successful implementation of digital media buying, and advertisers in Bosnia and Herzegovina are aware of its most distinctive qualities. The success of the media buying campaigns relies on brand objectives and choosing the means suited for fulfilling the given goals, which in turn leads to the findings that the focus of companies' strategies is directed towards the cost-efficient medium usage, rather than solely performance-oriented ones. Measurement of the effects and return on the investment depends on the success of setting up a goal and isolating digital from other marketing efforts.
\end{abstract}

Key words: digital advertising, media buying, CPC (Cost per Click), Bosnia and Herzegovina

\section{INTRODUCTION}

The Internet has become the essence of communication. Considering that, it is clear why online media is a playground where a brand's image, reputation, and existence are built. To keep up with the development of technology, advertisers are now using more advanced formats, more mature content, as well as more advanced and focused targeting tools and deliverable means of advertising. Most critical elements of seizing the full digital media buying potential include the measurment of digital advertising possibilities and the extent of using its most substantial qualities.

Digital advertising space is now the heart of the purchase process. Per PriceWaterCooper's study (PWC, 2017), $78 \%$ of users consulted a website before purchasing a product. It should not be surprising as consumers now on average spend more than three hours a month on instant messaging, four hours networking, and more than two hours emailing. The exact usage of the media, including all

\footnotetext{
Lejla Šehić, University of Sarajevo, School of Economics and Business in Sarajevo/eMedia Patch Sarajevo, Bosnia \& Herzegovina, Phone: +38762365595, E-mail: lejla_sehic@live.com

** Almir Peštek, PhD, Professor, University of Sarajevo, School of Economics and Business in Sarajevo, Bosnia \& Herzegovina, Phone: +38761152895, E-mail: almir.pestek@efsa.unsa.ba
} 


\section{Journal of Contemporary Management Issues}

possible digital channels, provides a huge advertising space, allowing advertisers to reach the users with exceptional targeting opportunities.

Although the Internet is, by nature a measurable and reporting medium, online strategies are still not based on an appropriate performance measure. There is a lot of research and papers assessing the effectiveness of digital advertising, with regard to its technical performance - clicks, impressions, click through rate (CTR), engagements, and engagement rate (ER) - and what the advertisers can do to improve the planning phase of digital media buying processes. However, not many papers deal with the assessment of individual effects of digital advertising on advertisers' business models - regarding valuable insights on the rise of brand awareness, brand attribution and sales. According to Li (2004), the effectiveness of digital advertising formats must be evaluated in terms of the general performance or their effectiveness, regardless of the type and context (Li, 2004).

Moreover, there is a noticeable absence of research data regarding the assessment and valuation of the post effects of digital media buying from the advertiser's perspective, which allows a clear assessment of the effectiveness of digital advertising. As a result, this study attempts to explore the effects of digital media buying for advertisers, using this marketing tool in Bosnia and Herzegovina, while analyzing the potential of digital media buying in Bosnia and Herzegovina. The analysis of the specific effects also addresses multiple addedvalue elements, such as the exploration of media, targeting options, and format usage, and their role in addressing advertising strategical objectives. Compared to other published works in the same field, focusing on a single segment of digital advertising (social media, search engine marketing - SEM, or the so-called banner advertising), this paper offers a holistic overview of advertisers' efforts, using all of the available media. Moreover, existing research is mostly experimental and is consumer-oriented, while this paper examines advertising from the advertiser's perspective.

\section{THEORETICAL BACKGROUND}

\subsection{Advertising ecosystem and key terms}

Advertising, as a business, social, cultural, and creative practice, has been continually changing throughout the years. Digital no longer represents fringe advertising media. Instead, it is considered as a group of expanding practices that, as a collective, is progressively becoming the dominant global advertising media form (McStay, 2010).

For advertisers, digital advertising is better compared to traditional marketing media. Evolving technology, smart data collection methods and more user-friendly targeting have had a substantial impact on the digital economy, as well as on our social development (Yuan et al., 2018). Figure 1 describes the advertising ecosystem, its players and the system - looking from the media buying towards the media selling side: advertisers who seek advertising solutions for their users, get their digital media campaign visible through advertising exchanges on distinctive publishers. 


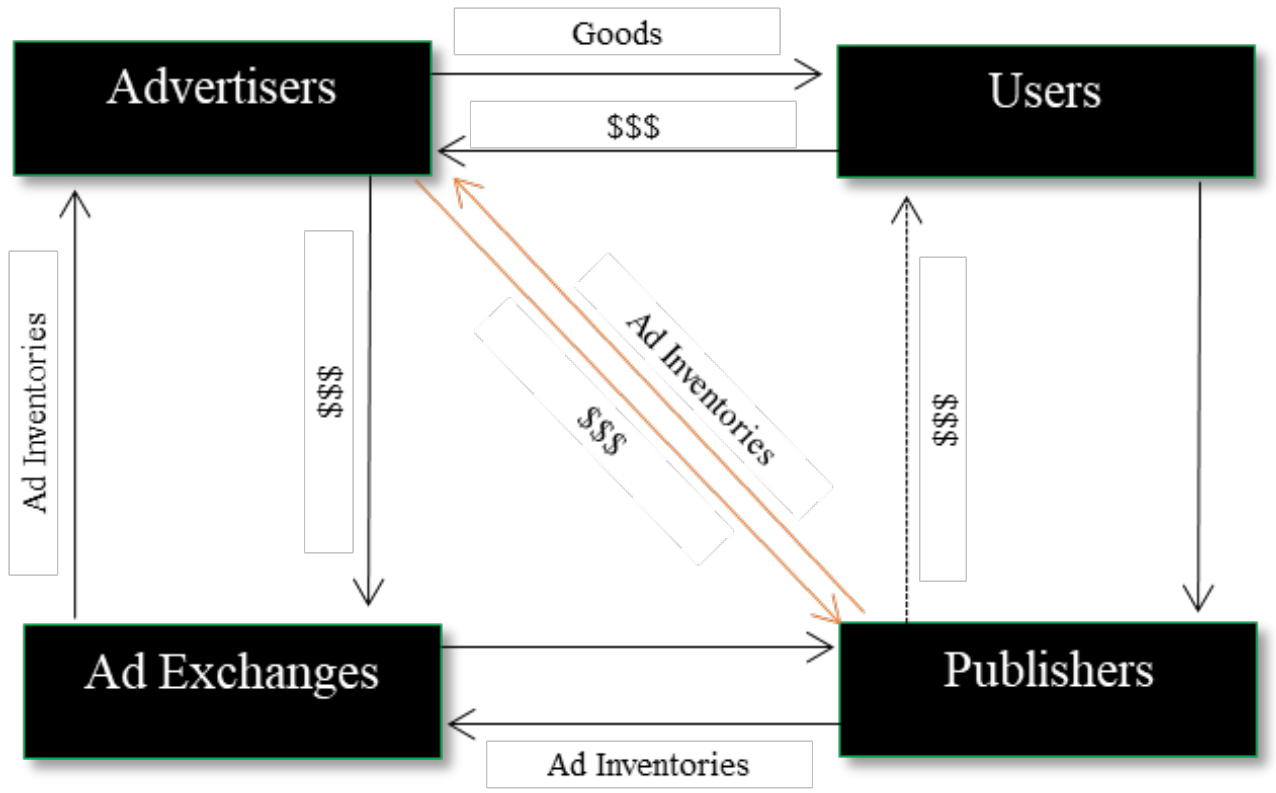

Figure 1. Advertising Ecosystem

Source: Adapted from Yuan et al. (2018)

Digital advertising, i.e. "brand- or product-related visual content created by a brand and that runs distinct from editorial content" (Campbell et al., 2014), is responsible for collecting the majority of revenue for publishers. Being one of the fastest-growing industries, digital advertising is an environment, where all players have to keep up with the trends. Advertisers use digital ads to generate demand, raise brand awareness, and finally stimulate the interest of potential customers for a product or service, through three common ways of buying media inventory: paying a premium, using programmatic buying, or buying media via Google, Facebook and other social media platforms in cost per click (CPC), or cost per mille (CPM) methods. Digital advertising refers to the actions of both selling (publishers) and buying (brands), while digital media buying addresses brands/advertiser's perspective only.

Today, the media market is facing numerous rapid changes, due to the rise of consumer demands, the constant development of technologies and the introduction of new devices. Spending and revenues in digital media advertising are growing faster when compared to the traditional media categories. According to eMarketer (2019), digital ad spending worldwide will total $\$ 316.42$ billion in 2020 . The share of digital spending will surpass the traditional channels with a $52.1 \%$ share by 2021 (eMarketer, 2019).

\subsection{Benefits, values and effects of digital media buying}

Knowledge of media buying effects is crucial for the creation of fundamental objectives of online media campaigns - an essential pillar of overall marketing strategizing. There is no doubt that marketers understand the consumer purchase path - numerous authors, scholars, and industry experts have described it as a process going from brand awareness, the creation of 


\section{Journal of Contemporary Management Issues}

brand attitude, expression of purchase intention, and finally, the purchase (Vakrastas and Ambler, 1999). Digital advertising can affect every stage of the consumer purchase path, while allowing media buyers to assess and measure the investment. The most significant advantage of using a mix of buying tools, starting with Google or Facebook, to more advanced direct and programmatic media buys, is the fact that advertisers can target and measure their efforts.

Having in mind that the majority of advertisers are facing limited budgets, industry is looking for effective tools and channels. In today's intensive competition between advertisers, the focus is on price reduction and all digital media players are trying to reduce their costs by all means. Online advertising is considered to be one of the most atractive options, as it has multiple benefits, including enormous content development opportunities, interaction with users, detailed targeting and lower costs than any other marketing tool (Peng, 2014).

Brettel (2010), Chatterjee (2003), and Rust (2004) summarize the effectiveness and accountability of digital advertising and all agree upon the fact that the value of online advertising means should be assesed with real campaign data, instead of tests and experiments. Several authors (Dahle'n, 2002; Lohtia et al., 2003; Manchanda et al., 2006) examined the effects of online banner ads on purchase behavior and proved the existence of a positive relationship between them. Baltas (2003) and Hanson (2000) report on a well-known indicator for evaluating the effectiveness of display advertisingCTR or click-through rate, which represents the portion of users who clicked on the ad, after seeing it. However, the advertising industry also uses other means of success, such as conversions, sales, or branding.

\subsection{Effective media buying strategy}

To be effective, digital advertising must be embedded in the overall marketing strategy. Rather than measuring data, using a variety of different indicators, it is critical for advertisers to synthesize and compare data between different media. An effective (social) media strategy should start with precisely stating the objectives, assessing the opportunities and choosing the right advertising form (Kumar and Mirchandani, 2013).

Effective (social) media measurement should focus on considering and understanding user motivation for (social) media usage, followed by the measurement of the advertising budget (Hoffman and Fodor, 2010). Wang (2006) suggested that engagement should not be regarded as the first metric of digital advertising success. Rather, advertising engagement should be considered as the ultimate goal.

Personalization plays an important role in rising click-through rates (CTR), but also view-through, as it boosts advertising effectiveness, but only with motive congruent content (Bleier and Eisenbeiss, 2015).

Troung et al. (2010) stated five important trends that the advertisers should pay attention to, when creating a strategy: permission-based advertising formats, high level of personalization, multiple screen campaigns, more interactivity and utilization based on performance metrics (Truong et al., 2010). Kumar and Mirchandani (2013) presented three new metrics - first one is the Customer Influence Effect (CIE), which represents the power of one user on others in relevant conversations. The Stickiness Index (SI) shows the power of a user, not only in social media conversations, but also beyond them, while the Customer Influence Value (CIV) calculates 
the value of a single user's influence on all other potential customers.

\section{METHODOLOGY}

The main research questions were defined as follows:

1 What are the advertisers' perceptions of digital advertising in Bosnia and Herzegovina and what is the potential of this type of advertising?

2 What are the effects of digital media buying on advertisers in Bosnia and Herzegovina - regarding brand awareness, brand attitudes, purchase intentions, and sales?

3 What is the optimal media buying strategy for advertisers in Bosnia and Herzegovina?

In-depth interviews, as the primary source of data, were conducted to collect data for this research. Interviews provided detailed data and insights, as they were assessed as the most appropriate tool for the topic of this research - developing detailed perspectives, integrating multiple opinions, describing processes and bringing intersubjectivity (Weiss, 2014). This method allowed authors to understand advertisers' perceptions, provided knowledge on the specific media buying effects and set the ground for establishing optimal media buying strategy recommendations.

In-depth interview questions were drawn from several available books (Strauss, 2001; McStay, 2010), journal papers (Karjaluoto \& Leinonen, 2009; Hollis, 2015; Vakrastas, 1999; Peng et al., 2014; Breuer \& Brettel, 2012) and industry reports (PWC, 2017; Kantar TNS, 2018). They were clustered into specific relevant topics for answering research questions by conducting face-to-face audio-recorded interviews, lasting 45-60 minutes.

Table 1. Interview guidelines

\begin{tabular}{|l|l|l|}
\hline $\begin{array}{l}\text { Objective/Research } \\
\text { question reference }\end{array}$ & Topic/Questions for discussion & Literature references \\
\hline $\begin{array}{l}\text { General questions/ } \\
\text { interviewee background }\end{array}$ & $\begin{array}{l}\text { Background } \\
\text { Company profile } \\
\text { Current position and scope of work }\end{array}$ & - \\
\hline $\begin{array}{l}\text { Digital media buying } \\
\text { potential awareness }\end{array}$ & $\begin{array}{l}\text { What are the benefits, challenges and limitations of } \\
\text { digital media advertising? } \\
\text { What are the known and used forms of digital } \\
\text { media buying? }\end{array}$ & $\begin{array}{l}\text { Karjaluoto \& Leinonen, } \\
2009 \\
\text { McStay, 2010 }\end{array}$ \\
\hline $\begin{array}{l}\text { A strategic approach to } \\
\text { Digital Media Advertising }\end{array}$ & $\begin{array}{l}\text { Do you have a digital media strategy as a part of the } \\
\text { marketing strategy? } \\
\text { Do you have defined and specific digital media } \\
\text { buying budgets? } \\
\text { Do you have in-house staff or do you instead } \\
\text { outsource digital media expertise? }\end{array}$ & Strauss, 2001 \\
\hline
\end{tabular}




\begin{tabular}{|c|c|c|}
\hline $\begin{array}{l}\text { Digital media potential } \\
\text { usage: Types and ways } \\
\text { of digital media buying } \\
\text { usage, media, digital media } \\
\text { campaign objectives, } \\
\text { targeting }\end{array}$ & $\begin{array}{l}\text { What are the common branding objectives of } \\
\text { your digital media buying (reputation, awareness, } \\
\text { recognition, purchase intent)? } \\
\text { How do you measure the impact of digital media } \\
\text { buying on your brand objectives? } \\
\text { Which media and formats do you usually use } \\
\text { in your media buying efforts (CPC, direct, } \\
\text { programmatic; display, search, social)? } \\
\text { Which targeting methods do you usually use in } \\
\text { your media buying efforts? }\end{array}$ & $\begin{array}{l}\text { Karjaluoto \& Leinonen, } \\
2009 \\
\text { PWC, } 2017\end{array}$ \\
\hline $\begin{array}{l}\text { Effects of digital media } \\
\text { buying: awareness, } \\
\text { consideration, purchase, ROI }\end{array}$ & $\begin{array}{l}\text { What are your parameters of success for media } \\
\text { buying? } \\
\text { How do you measure the effects of digital media } \\
\text { advertising? } \\
\text { How do you measure the media buying cost } \\
\text { efficiency? } \\
\text { What are the short and long-term effects of digital } \\
\text { media buying and how do you measure them? } \\
\text { (awareness, interest, loyalty, advocacy, purchase } \\
\text { intent, sales) } \\
\text { Does more spending imply more sales volume? } \\
\text { Do you believe in the diminishing effect of digital } \\
\text { awareness? } \\
\text { How much does the media buying boost your } \\
\text { company's turnover? } \\
\text { What are the effects of media buying on online and } \\
\text { offline sales: purchasing behavior of consumers - is } \\
\text { digital media exposure measurable, what are the } \\
\text { effects on different distribution channels? }\end{array}$ & $\begin{array}{l}\text { Hollis, } 2015 \\
\text { Vakrastas, } 1999 \\
\text { Peng et al., } 2014 \\
\text { Breuer \& Brettel, } 2012 \\
\text { PWC, } 2017\end{array}$ \\
\hline $\begin{array}{l}\text { Future of digital advertising } \\
\text { in Bosnia and Herzegovina }\end{array}$ & $\begin{array}{l}\text { What are your thoughts on trends: social, mobile, } \\
\text { video, native type of ads? }\end{array}$ & Kantar TNS, 2018. \\
\hline
\end{tabular}

Source: Multiple authors

Respondents were categorized into two groups: industry experts, i.e., experts in an area, and advertisers, i.e., experts who use digital media as an element of their marketing mix. The sampling method used was partially business convenience, i.e., top industry players from fast-moving consumer goods (FMCG), fashion and beauty, oil, insurance, telecommunications, and retail; media executives and experienced media planners from advertising agencies.

The authors approached all potential interviewees via LinkedIn, considering that having a professional network account is an appropriate entry barrier to eliminate those, who would not be the right fit, regarding their knowledge on digital media. The conversation later continued via email or phone and resulted in individual interviews, conducted by faceto-face meetings, either in respondents' offices, or at third-party locations, lasting up to 1.5 hours. All interviews were held in the Bosnian language, audio recorded, transcribed, and translated into English. Respondent profile is presented by Table 2 and Table 3, includes both advertisers and experts who participated in research, respectively. 
Table 2. Advertisers' profile

\begin{tabular}{|c|c|}
\hline Company & Interview \\
\hline \multicolumn{2}{|l|}{ FMCG } \\
\hline FMCG 1 & Marketing Manager \\
\hline FMCG 2 & Marketing Manager \\
\hline \multicolumn{2}{|l|}{ RETAIL } \\
\hline RETAIL 1 & Marketing department \\
\hline RETAIL 2 & Marketing Manager \\
\hline RETAIL 3 & Marketing Manager \\
\hline \multicolumn{2}{|l|}{ INSURANCE } \\
\hline INSURANCE 1 & Online Manager \\
\hline INSURANCE 2 & Marketing Manager \\
\hline INSURANCE 3 & Marketing Manager \\
\hline \multicolumn{2}{|c|}{ BEAUTY, FASHION, APPAREL } \\
\hline BEAUTY & Digital Manager \\
\hline FASHION 1 & CEO \\
\hline FASHION 2 & Marketing Manager \\
\hline \multicolumn{2}{|l|}{ OIL } \\
\hline OIL 1 & Marketing Manager \\
\hline OIL 2 & Marketing Manager \\
\hline \multicolumn{2}{|c|}{ TELECOMMUNICATION } \\
\hline TELECOM 1 & Marketing Manager \\
\hline TELECOM 2 & Marketing Manager \\
\hline
\end{tabular}

Table 3. Experts' profile

\begin{tabular}{|l|l|}
\hline Expert & Position, Agency \\
\hline Expert 1 & Founder, Digital Agency \\
\hline Expert 2 & $\begin{array}{l}\text { Marketing Manager, } \\
\text { Multinational IT Company }\end{array}$ \\
\hline Expert 3 & $\begin{array}{l}\text { Director of Digital, Full Service } \\
\text { Marketing Agency }\end{array}$ \\
\hline Expert 4 & $\begin{array}{l}\text { Digital Account Manager, Full } \\
\text { Service Marketing Agency }\end{array}$ \\
\hline Expert 5 & $\begin{array}{l}\text { Vice President of Account } \\
\text { Management, Digital Advertising } \\
\text { Agency }\end{array}$ \\
\hline Expert 6 & $\begin{array}{l}\text { Executive Director, Digital } \\
\text { Advertising Agency }\end{array}$ \\
\hline
\end{tabular}

Source: Primary research data

\section{DATA ANALYSIS AND DISCUSSION}

\subsection{Perceptions and knowledge of digital advertising}

After the in-depth interviews with experts, working with digital media in Bosnia and Herzegovina, it can be concluded that the industry is challenging, as all sides face a crucial problem of the lack of knowledge, leading to media space not being exploited to the full potential. Even though the costs are low, especially comparing to the US and EU markets, there are low entry barriers, but the media buying potential is still insufficiently exploited. Domestic publishers do not develop properties and offer high prices for average results, which is why advertisers in Bosnia and Herzegovina mostly rely on self-serving media buying tools, such as Google and Facebook. Despite that, experts agree that all advertisers should keep in mind that the domestic market needs to be protected and, thus, keep investing in direct buying, as it will eventually lead to better conditions for all.

Analyzing the responses to the question: What are the advertisers' perceptions of digital advertising in Bosnia and Herzegovina and what is the potential of this type of advertising?, it can be concluded that advertisers in Bosnia and Herzegovina are well aware of digital media buying benefits and drawbacks, knowing the potential of its usage: "The advantages include quick, simple, and easy production of content. We see the effects of media buying immidiately and evaluate which format works best in real time. There is a two-way communication with potential customers, which is extremely valuable. Finally, there is the opportunity for making the campaign optimization while it is live." (Insurance 1). This supports Peng's note 


\section{Journal of Contemporary Management Issues}

that digital advertising is one of the most prominent marketing channels because of the low costs, targeting possibilities, interactivity, and content development opportunities (Peng, 2014).

Besides highlighting benefits, advertisers also stated that digital adveritising has huge drawbacks regarding manipulation of data, audience reach, and advertising display, which is never as transparent as it should be. The respondents also stated that the biggest challenge is: "Fighting false figures and users on YouTube, Instagram, Facebook that fictitiously show ads, and are not real market users." (Telecom 1).

Even though the advertisers are not using the full potential of media buying, they are familiar with all the relevant methods, including the most common ones used in Bosnia and Herzegovina - self-served Google, Facebook and direct buying. Industry experts, working in the US, UK and Australian markets, confirm that the potential is not used to the fullest. Expert 2 stresses that the lack of understanding of the ecosystem might be the reason why advertisers are not thinking outside the costper-click box: "I can say with certainty that the potential for digital advertising is not used to the fullest. I believe many publishers still rely only on selling the media space directly to the advertisers and that Ad exchange is underutilized."

\subsection{Brand objectives and implementation means}

Advertisers agree that setting objectives should be the initial step, prior to launching any campaign and that their brand objectives mostly focus on awareness and purchase intention, rather than sales. Their strategies are set up in line with the overall marketing strategy, and developed with both in-house and agency teams: "Digital advertising has the largest share in our marketing mix as the industry motivates us to be creative in approaching our target audience. We have to differentiate our brand and there is no better way of doing it than with new and up to date content served online" (Fashion 2). Kumar and Mirchandani (2013) noted that an effective media strategy should have precise marketing objectives, so the advertisers can assess the opportunities and select appropriate implementation means. The research participants do not skip defining marketing objectives; however, they still rely on the most convenient forms, rather than the effective ones. Focusing on Facebook and Google as CPC methods, there is room for development, especially in terms of expanding direct media buying practices: "Google Search/Display and YouTube are more efficient and cheaper channels compared to direct and that is why we focus on them" (Fashion 1).

\subsection{Measurement of effects and ROI}

When evaluating responses to the question: What are the effects of digital media buying on advertisers in Bosnia and Herzegovina - regarding brand awareness, brand attitudes, purchase intentions, and sales, it can be concluded that advertisers in Bosnia and Herzegovina struggle to connect their objectives with effects, mainly due the lack of sales-oriented campaigns. Most of them still keep digital advertising as a part of the spectrum within their marketing mixes and do not isolate digital campaigns, which is another reason, why is it so hard to track the actual digital campaign effect. They mainly rely on metrics, such as impressions, clicks, engagements, CTRs, ERs, but rarely on conversions (purchases), since not many of the respondants have implemented an e-commerce initiative. However, advertisers still rely on actual data, rather 
than experiments, just like Brettel (2010), Chatterjee (2003) and Rust (2004) agreed.

From an expert's experience, a significant shift is happening from chasing down impressions, clicks, and click-through rates to the actual conversions. In the end, profit is the ultimate goal for each campaign, directly or indirectly. Therefore, conversions (sales) might be the most crucial metric for today's digital marketing campaigns.

Even if the goal of the campaign is not selling, advertisers nevertheless analyze ROI and take it as a significant point, when evaluating the success of a campaign. Advertisers, who seek to build brand equity through online advertising, should ensure that the impression of advertising establishes a predisposition toward the brand. The likelihood of considering a brand for purchase will be dependent on impressions, based on prior experience - including exposure to advertising up to that point in time (Hollis, 2005).

\subsection{Optimal strategy and managerial recommendations}

The question: What is the optimal media buying strategy for advertisers in Bosnia and Herzegovina, was a challenge for both experts and advertisers. Both sides agreed that it is most important to follow best practices from global markets: "The important point of the future of digital media buying is content - advertisers state that it will be the key to selling products online" (Expert 1). As Google will undoubtedly remain the most valuable medium for advertisers, where the majority of search ad clicks occur, digital media strategy has to focus on SEM. Paid search ads are not intrusive and, yet, have better effectiveness, compared to display ads (Sen, 2005): "Leveraging innovative and custom rich media executions that are crafted to deliver unique, personalized messages to the user should be the winning tactic for the future. Finally, the video is still going strong, with predictions that it will drive 3/4 of all web traffic in the following years " (Expert 5).

When speaking of setting up the strategy, advertisers have to define the objectives, before kicking off with their digital campaigns, to be able to evaluate the effects promptly. It is said that advertisers have to understand their audiences in the strategy formulation phase, to be able to seize the full targeting potential - not just using the default aspects: geography and demography. It can also be concluded that the most recent recommendations by Troung et al. (2010) should be addressed. Five key trends, which advertisers have to pay attention to, when building their strategies are: advertising focusing on permission, more ad personalization, multiple screens included in targeting, more interactivity and focus on performance (Truong, McColl and Kitchen, 2010).

\section{CONCLUSION, LIMITATIONS AND FUTURE RESEARCH DIRECTIONS}

This paper shows that advertisers in Bosnia and Herzegovina struggle with using the full digital media buying potential, even though they are well aware of its benefits. Advertisers have showed knowledge of advantages and drawbacks of digital advertising, agreeing upon the fact that its most distinctive qualities are: audience targeting, speed, efficiency, price, transparency, and real-time assessment, supporting experts' opinions in terms of digital advertising fundamental values, all supporting Peng's (2014) conclusions. 


\section{Journal of Contemporary Management Issues}

The focus of advertisers' strategies goes towards cost-efficient usage of the medium, rather than solely performance-oriented ones. This can be seen through the fact that advertisers in Bosnia and Herzegovina focus on Google and Facebook self-served buying, as they find them effective in terms of return on investment. On the other hand, Kumar and Mirchandani (2013) stated that an effective (social) media strategy should start with precise objectives and then assess the opportunities and choose right implementation means. Marketing ROI should be evaluated at each stage of involvement, by using appropriate methods (Kaufman and Horton, 2015).

This study supports PwC's (2017) paper conclusions that although the Internet is, by nature, a measurable medium, online strategies still do not focus on the right performance measurement. Domestic companies do not use a unified approach to digital advertising. Instead, they use it in combination with traditional advertising efforts, which additionally makes it harder to assess the performance and real effects, in terms of brand awareness, purchase intentions and sales. Advertisers, however, confirm they focus on two fundamental objectives building awareness and shaping attitude, as Dou (2010) stated. For the ones, solely relying on awareness and pre-purchase attitude,

Table 4. Summary of findings

\section{Research Implication}

The benefits of digital advertising include speed, simplicity, standardization, feedback being easily obtained, and two-way communication.

Advertisers are stating objectives in the initial phase of the digital campaign, yet not choosing the mean based on it, but rather focusing on cost efficiency as the crucial element of the decision-making process. it becomes even harder to evaluate the overall digital media buying effects, as there is a lack of means for connecting online performance with offline results. Only a limited number of companies with an e-commerce focus on sales (Retail, Insurance) and can see the exact sales peaks, as a specific effect of media buying efforts.

Kaufman and Horton (2015) implied that the higher the volume of the user-generated content, the higher the direct effect on marketing ROI. The research findings, on the other hand, show that advertisers in Bosnia and Herzegovina do not find the digital media buying input essential for the generated return on investment. Instead, they stress the ability to manipulate with limited budgets and content, which becomes one of the critical lessons regarding creating optimal media buying strategy, along with the up-to-date medium of choice, right targeting, and mobile-centric advertising. It is to be concluded that advertisers in Bosnia and Herzegovina should follow Hoffman and Fodor's (2010) conclusions that the effective (social) media measurement should start with understanding customer motivations for media usage and then measuring investment in digital advertising as they engage with a brand and its objectives. Table 4 provides a summary of research findings.

\section{Recommendation/Support, Author (Year)}

Online advertising is one of the most used and effective marketing channels due to its benefits of rich content provision, interactivity, great targeting, and low costs (Peng, 2014).

Effective media strategy has to have clearly defined marketing objectives to be able to evaluate opportunities and select the appropriate form (Kumar and Mirchandani, 2013). 
Research Implication

Advertisers rarely track the effects of digital media buying efforts, online campaign is not isolated from the offline one, but still rely on actual data when making decisions (clicks, impressions, ROI compared to previous periods).

Key of digital advertising success: content, SEM utilization, personalized messages, video, and custom rich media execution.

Source: Primary and secondary research

The conducted research was of an exploratory and qualitative character, and even though the information collected using in-depth interviews and secondary research is valuable and relevant, the validity of the research would have been improved, if there had been a chance to collect quantitative data of the analysed qualitative subject. For further exploration of the topic, authors recommend investigating the market state in the region, comparing the data and finding good case practices to create valuable, quantifiable learning.

\section{REFERENCES}

1. Baltas, G. (2003). Determinants of Internet Advertising Effectiveness: An Empirical Study. International Journal of Market Research, 45(4), 1-9.

2. Brettel, M., \& Spilker-Attig, A. (2010). Online advertising effectiveness: a cross-cultural comparison. Journal of Research in Interactive Marketing, 4(3), 176-196.

3. Breuer, R., \& Brettel, M. (2012). Short- and Long-term Effects of Online Advertising: Differences between New and Existing Customers. Journal of Interactive Marketing, 26(3), 155-166.

4. Campbell, C., Cohen, J., \& Ma, J. (2014). Advertisements Just Aren't

\section{Recommendation/Support, Author (Year)}

Advertisers have to rely on actual data rather than experiments when analyzing campaign performance (Brettel, 2010).

Advertisers have to ensure that the impression of advertising will establish a predisposition toward a brand (Hollis, 2005).

Five main trends in advertising: permission-based advertising, high level of personalized ads, multiple screens, and formats with an increased level of interactivity and focus on performance (Troung, McColl and Kitchen, 2010).

Advertisements Anymore. Journal of Advertising Research, 54(1), 7-10.

5. Chatterjee, P., Hoffman, D.L., \& Novak, T.P. (2003). Modeling the clickstream: implications forweb-based advertising efforts. Marketing Science, 22(4), 520-41.

6. Dahle'n, M. (2001). Banner advertisements through a new lens. Journal of Advertising Research, 41(4), 23-30.

7. Digital Consulting $\mid$ Digital Advertising | Media Planning | Media Buying | Global Traffic. (2018). Advertise in Bosnia-Herzegovina. [online] Available at: https://globalrevgen.com/advertisein-bosnia-herzegovina/ [Accessed 21 Jun. 2018].

8. Dou, W., Lim, K., Su, C., Zhou N., \& Cui N. (2010). Brand Positioning Strategy Using Search Engine Marketing. MIS Quarterly, 34(2), 261-279.

9. Drèze, X.n \& Hussherr, F. (2003). Internet advertising: Is anybody watching?. Journal of Interactive Marketing, 17(4), 8-23.

10. eMarketer (2019). GLOBAL $A D$ SPENDING - The Emarketer Trend for 2019. New York: eMarketer.

11. eMarketer (2018). Data and Research on Digital for Business Professionals. New York: eMarketer.

12. Hanson, W. (2000). Principles of Internet Marketing. Cincinnati, Ohio: SouthWestern College Publishing. 
13. Hoffman, D., \& Fodor, M. (2010). Can You Measure the ROI of Your Social Media Marketing. MIT Sloan Management Review, 52(1), 40-50.

14. Hollis, N. (2005). Ten Years of Learning on How Online Advertising Builds Brands. Journal of Advertising Research, 45(02), 255-268.

15. Kantar TNS (2018). Understanding Digital Consumers. Understanding Digital Consumers Worldwide. Sarajevo: Connected Life, pp.1-20.

16. Karjaluoto, H., \& Leinonen, H. (2009). Advertisers' perceptions of search engine marketing. International Journal of Internet Marketing and Advertising, 5(1/2), 95-112.

17. Kaufman, I., \& Horton, C. (2015). Digital Marketing: Integrating Strategy and Tactics with Values. 1st ed. New York: Taylor and Francis.

18. Kumar, V., \& Mirchandani, R. (2013). Increasing the ROI of social media marketing. IEEE Engineering Management Review, 41(3), 17-23.

19. Lohtia, R., Donthu, N., \& Hershberger, E.K. (2003). The impact of content and design elementson banner advertising click-through rates. Journal of Advertising Research, 43(4), 410-418.

20. Manchanda, P., Dube', J.-P., Goh, K.Y., \& Chintagunta, P.K. (2006). The effect of banner advertising on internet purchasing. Journal of Marketing Research, 43(1), 98-108.

21. McStay, A. (2010). Digital Advertising. 1st ed. London: Palgrave Macmillan, $1-43$.

22. Nielsen.com. (2018). How Frequency of Exposure can Maximise the Resonance of your Digital Campaigns. [online] Available at: http://www. nielsen.com/au/en/insights/news/2017/ how-frequency-of-exposure-can-max- imise-the-resonance-of-your-digitalcampaigns.html [Accessed 16 Jun. 2018].

23. Peng, J., Zhang, G., Zhang, S., Dai, X., \& Li, J. (2014). Effects of online advertising on automobile sales. Management Decision, 52(5), 834-851.

24. PwC (2017). Measuring the effectiveness of online advertising - Study conducted by PwC for IAB France and the SRI. France: PwC.

25. PwC. (2018). PwC. [online] Available at: https://www.pwc.com/ [Accessed 7 Nov. 2018].

26. Rust, R.T., Ambler, T., Carpenter, G.S., Kumar, V., \& Srivastava, R.K. (2004). Measuring marketing productivity: current knowledge and future directions. Journal of Marketing, 68(4), 76-89.

27. Sen, R. (2005). Optimal search engine marketing strategy. International Journal of Electronic Commerce, 10(1), 9-25.

28. Strauss, J., \& Frost, R. (2001) Emarketing, Upper Saddle River, NJ: PrenticeHall.

29. Tihi, B., \& Kurtović, E. (2015). Istraživanje marketinga. 6.izdanje. Sarajevo: Ekonomski fakultet u Sarajevu.

30. Truong, Y., McColl, R., \& Kitchen, P. (2010). Practitioners' perceptions of advertising strategies for digital media. International Journal of Advertising, 29(5),709-725.

31. Vakratsas, D., Feinberg, F.M., Bass, F.M., \& Kalyanaram, G. (2004). The shape of advertising response functions revisited: a model of dynamic probabilistic thresholds. Marketing Science, 23(1), 109-119.

32. Vakratsas, D., \& Ambler, T.(1999). How Advertising Works: What Do We 
Really Know?. Journal of Marketing, 63(1), 26-43.

33. Wang, A. (2006). Advertising Engagement: A Driver of Message Involvement on Message Effects. Journal of Advertising Research, 46(4), 355-368.

34. Weiss, R. (2014). Learning from strangers. New York: The Free Press.
35. Wittink, D.R. (1977). Exploring territorial differences in the relationship between marketing variables. Journal of Marketing Research, 14(2), 145-155.

36. Yuan, S., Zainal Abidin, A., Sloan, M., \& Wang, J. (2018). Internet Advertising: An Interplay among Advertisers, Online Publishers, Ad Exchanges and Web Users. London: Department of Computer Science, University College London.

\section{EFEKTI ZAKUPA DIGITALNIH MEDIJA NA OGLAŠIVAČE}

Sažetak. Iako Internet postaje ključnim aspektom komunikacije, iz perspektive oglašivača, digitalno oglašavanje ostaje nedovoljno istraženo. $U$ ovom se radu analiziraju efekti zakupa digitalnih medija na oglašivače u Bosni $i$ Hercegovini, uz proučavanje metodologije korištenja digitalnih medija, koja ne uzima u obzir samo tekuće efekte. Pritom se koristi kombinacija analize sekundarnih rezultata istraživanja s $k v a-$ litativnim istraživačkim tehnikama. Empirijski dio rada temelji se na dubinskim intervjuima s oglašivačima i predstavnicima industrije digitalnog oglašavanja. Percepcije i poznavanje digitalnog oglašavanja ključni su pokretači uspješne primjene zakupa digitalnih medija, a navedenog su svjesni i oglašivači iz Bosne i Hercegovine. Uspješnost medijskih kampanja oslanja se na ciljeve tržišne marke te izbor sredstava, prilagođenih za njihovu realizaciju, što, nadalje, dovodi do saznanja o fokusu strategija poduzeća prema troškovno efikasnom korištenja medija, umjesto isključivog usmjerenja prema ciljevima. Mjerenje efekata i povrata na investiciju ovisi o uspješnosti postavljanja ciljeva te izdvajanja digitalnog marketinga od ostalih marketinških napora.

Ključne riječi: digitalno oglašavanje, zakup medija, trošak po kliku, Bosna i Hercegovina 